\title{
The Effect of Feeding with Resveratrol on Myogenin and mTOR Levels in Mice
}

\author{
Resveratrol ile Beslenmenin Farelerde Myogenin ve mTOR Düzeyleri Üzerine Etkisi
}

\author{
Serap Andaç Öztürk ${ }^{1}$, Gül Kızıltan², Erkan Yurtçu³, Didem Bacanlı ${ }^{4}$ Yeşim Korkmaz Kasap ${ }^{5}$ Beril Köse $^{6}$
}

Geliş tarihi/Received: $10.05 .2020 \bullet$ Kabul tarihi/Accepted: 01.10.2020

\begin{abstract}
Aim: It is reported that resveratrol may induce muscle hypertrophy and myogenesis. Accordingly, resveratrol is promising for the treatment of muscle diseases and ergogenic aid for athletes. In this study it is aimed to observe the effects of resveratrol on myogenin and mTOR levels and muscle mass.

Material and Methods: The study is performed on 14 Swiss albino young adult mice at Başkent University Experimental Animal Research Center. The mice are divided randomly into study (n:7) and control (n:7) groups. During consecutive 7 days, $20 \mathrm{mg} / \mathrm{kg}$ trans-resveratrol was given to the study group intraperitoneally. After the seventh day administration, the right gastrocnemius muscles are disected, weighted and stored at $-80^{\circ} \mathrm{C}$ for mTOR and myogenin analysis. Then, myogenin and mTOR levels are determined by enzyme-linked immunosorbent assay (ELISA) method in homogenised muscle mass.

Results: According to mean myogenin and mTOR levels, there was no significantly difference between groups ( $\mathrm{p}>0.05)$. Total body weight and the right gastrocnemius muscle weight of the study group $(22.11 \pm 3.22 \mathrm{~g}, 0.09 \pm 0.03 \mathrm{~g}$, respectively) at the 7 th day was found significantly lower than control group $(28.63 \pm 3.80 \mathrm{~g}, 0.12 \pm 0.02 \mathrm{~g}$, respectively) $(\mathrm{p}<0.05)$.

Conclusion: It was observed that resveratrol administration had no effect on myogenin and mTOR levels which is a fore-step for muscle hypertrophy. On the other hand, interestingly total body weight and muscle mass decrease was observed in the study group. The effects of resveratrol on muscle tissue is a relatively less studied topic. However, the authors are suggesting more studies on the resveratrol usage or administration for the effective dose and time interval investigation.
\end{abstract}

Keywords: Resveratrol, gastrocnemius, weight, mTOR, myogenin

\section{ÖZET}

Amaç: Resveratrolün kas hipertrofisi ve miyogenezi indükleyebileceği bildirilmektedir. Bu nedenle, resveratrol kas hastalıklarının tedavisi ve sporcular için ergojenik yardım olarak umut vermektedir. Mevcut çalışmada, resveratrolün miyogenin ve mTOR düzeyleri ve kas kütlesi üzerindeki etkilerinin gözlenmesi amaçlanmıştır.

Note: This study has been translated from doctoral thesis to article and presented as an oral presentation in the $15^{\text {th }}$ International Conference on Clinical Nutrition May 24-26, 2018, Vienna, Austria.

1. İletişim/Correspondence: İstanbul Aydın University, Halit Aydın Campus, Health Science Faculty Nutrition and Dietetics Department, Beşyol, İstanbul, Turkey E-posta: serapozturk@aydin.edu.tr • ๑ https://orcid.org/0000-0002-6253-4118

2. Başkent University Bağlıca Campus, Health Science Faculty, Nutrition and Dietetics Department, Ankara, Turkey • ๑ https://orcid.org/0000-0001-5012-5838

3. Başkent University Bağlica Campus, Medicine Faculty, Medical Biology, Ankara, Turkey • ๑ https://orcid.org/0000-0003-4930-8164
4. Başkent University Bağlıca Campus, Experimental Animal Research Center, Ankara, Turkey • (1) https://orcid.org/0000-0001-5740-4979

5. Başkent University Bağlıca Campus, Medicine Faculty, Medical Biology, Ankara, Turkey • (1) https://orcid.org/0000-0002-0950-7890

6. Başkent University Bağlıca Campus, Health Science Faculty, Nutrition and Dietetics Department, Ankara, Turkey • (1) https://orcid.org/0000-0002-5173-2389 
Gereç ve Yöntem: Çalışma, Başkent Üniversitesi Deney Hayvanları Araştırma Merkezi'nde 14 Swiss albino genç erişkin fare üzerinde yürütülmüştür. Fareler rastgele olarak çalışma (n:7) ve kontrol grubuna (n:7) ayrılmıştır. Çalışma grubuna ardışık 7 gün boyunca $20 \mathrm{mg} / \mathrm{kg}$ transresveratrol intraperitoneal yol ile verilmiştir. Yedinci gün uygulamasından sonra farelerin gastroknemius kas diseksiyonları yapılarak, ağırlıkları kaydedilmiş ve miyogenin, mTOR analizleri için $-80{ }^{\circ} \mathrm{C}$ 'de saklanmıştır. Myogenin ve mTOR düzeyleri homojenize kas dokusundan enzim bağlı immunosorbent analizi (ELISA) yöntemi kullanılarak saptanmıştır.

Bulgular: Gruplar arasında miyogenin ve mTOR düzey ortalamaları açısından anlamlı farklılık saptanmamıştır (p>0.05). Çalışma grubunun vücut ağırlığı ve sağ gastroknemius kasının 7. gün ağırlığı (sırasıyla, $22.11 \pm 3.22 \mathrm{~g}, 0.09 \pm 0.03 \mathrm{~g}$ ), kontrol grubuna göre anlamlı derecede düşük bulunmuştur (sırasıyla, $28.63 \pm 3.80 \mathrm{~g}, 0.12 \pm 0.02 \mathrm{~g})(\mathrm{p}<0.05)$.

Sonuç: Bu çalışmada resveratrol uygulamasının kas hipertrofisi için önemli bir basamak olan miyogenin ve mTOR düzeyleri üzerinde bir etkisinin olmadığı gözlenmiştir. Buna ek olarak çalışma grubunda ilginç olarak vücut ve kas dokusu ağırlığı daha düşük saptanmıştır. Resveratrolün kas dokusu üzerindeki etkileri nispeten daha az çalışılmış bir konudur bu nedenle etkilerinin belirlenebilmesi için etkili doz ve zaman aralığı hakkında daha fazla çalışmaya ihtiyaç vardır.

Anahtar kelimeler: Resveratrol, gastroknemius, ağtrlık, mTOR, miyogenin

\section{INTRODUCTION}

Resveratrol (RSV), is a stilbenoid that is present in many plants, especially in grape, has two isomers: cis and trans forms, but trans form seems to have major biological effects (1). RSV has demonstrated many beneficial effects, including antiinflammatory, antioxidant, neuroprotective, and anticancer effects (2). Besides these effects it is also indicated that RSV can regulate the skeletal muscle fiber type transformation (3), increase exercise performance (4), and exhibit protective effects against oxidative damage and muscle atrophy in muscle disuse models (including hindlimb unloading and denervation) (5). In addition, RSV promotes muscle differentiation and hypertrophy by controlling muscle-specific proteins like myogenic regulatory factors (MRFs) (6).

Mammalian target of rapamycin (mTOR) is one of the key regulator of cell growth, proliferation, and metabolism (7). It is shown that insulin like growth factor-1 (IGF-1)/phosphatidylinositol 3-kinase (PI3K)/ Akt (Protein B kinase)/mTOR signaling pathway has a role in the regulation of skeletal muscle hypertrophy (8). Myogenesis depends on the differentiation potency of the satellite cells providing the formation of new muscle cells to differentiate to new fibrillary structures (9). The myogenesis process is under the control of a wide variety of myogenic transcriptional factors and kinases (10,11). These basic helix-loophelix transcription factors which are specific for muscle, also known as myogenic regulatory factors (MRFs), [e.g. Myogenic Factor 5 (Myf5), Myoblast Determination Protein (MyoD), myogenin, and muscle spesific regulatory factor 4 (MRF4)] (9). Myogenin expression, begining with myotubule formation, is necessary for the development of functional skeletal muscle (12) and is the critical step in myogenesis (13).

Resveratrol, can directly affect skeletal muscle metabolism and development (14), inducing myogenesis by stimulating Akt (protein kinase B)/ mTOR pathway $(15,16)$, one of the major pathways in muscle hypertrophy (17), and myogenic factors. However its effect on myogenic factors has not been studied sufficiently. The aim of this study, is to investigate the possible effect of resveratrol on myogenic transcription factor, a key factor in the late stages of myogenic transcriptional factors, as well as on mTOR levels which is an important kinase for myogenesis and on muscle mass.

\section{MATERIAL AND METHOD}

This study was approved by the decision of Başkent University Medical and Health Sciences Research 
Council and Experimental Animal Ethics Board, dated $11 / 05 / 2015$ under number of 15/23. Mus musculusSwiss albino type, young-adult (7-weeks old) with normal body weight male mice were used. The study was conducted at Başkent University Experimental Animal Research Center. Experimental animals were brought to the laboratory one week before the study for adaptation. Mice were housed and maintained at room temperature $22 \pm 1{ }^{\circ} \mathrm{C}$, relative humidity 50 $60 \%$, light period as, 12 hours light/12 hours dark. Water and pellet access of mice was provided as ad libitum, throughout the study. According to the results of power analysis, this study was performed with a total of 14 Swiss Albino male mice, including the study group and control group, consisted of 7 mice. The mice were randomly selected for each of the study groups. The study group received $20 \mathrm{mg} / \mathrm{kg} /$ day transRSV intraperitoneal injection for 7 consecutive days at the same time. The effects of RSV intervention on body weight, gastrocnemius muscle weight, mTOR and myogenin levels were examined in homogenised muscle mass. At the beginning and the seventh day of the study, weights of the mice were measured and recorded using a precision scale.

\section{Muscle Weights Determination}

On the 17th day, 1 hour after the intraperitoneal (IP) administration of trans-resveratrol, the right gastrocnemius muscle of the mice were isolated under general anesthesia. General anesthesia was given by intraperitoneal administration of ketamine at a dose of $90 \mathrm{mg} / \mathrm{kg}$ and xylazine at a dose of 10 $\mathrm{mg} / \mathrm{kg}$. The weights of the disected muscles were measured using a precision weighing scale and stored at $-80{ }^{\circ} \mathrm{C}$ in sterile containers for ELISA analysis and the sacrification was performed with $250 \mathrm{mg} / \mathrm{kg}$ IP ketamine application.

\section{mTOR and Myogenin ELISA Analyzes}

Protein levels of the homogenised muscle samples were determined by the Bradford Assay. Myogenin (MyBioSource) and mTOR (MyBioSource) were measured by Elisa according to the manufacturer's instructions. Briefly, samples were homogenized in a glass homogenisator. Standards were prepared using albumin. Both standards and samples were incubated with Bradford reagent in a dark room. After incubation all wells were read at $596 \mathrm{~nm}$. The slope was prepared using standards and protein levels of samples were calculated. Myogenin (MyBioSource, USA, Cat. No: MBS065750) and mTOR (MyBioSource, USA, Cat.No: Cat No. MBS260864) were measured by Elisa according to the manufacturer's instructions. Briefly, samples and standards supplied by the manufacturer were added to precoated 96 well ELISA plates and incubated at $90 \mathrm{~min}$ in $37^{\circ} \mathrm{C}$. At the end of the incubation period ELISA plates were washed and avidin biotin peroxidase complex were added. ELISA plates were incubated again and antigen antibody complexes were colorized by horseradish peroxidase (HRP) and 3,3',5,5"-tetramethylbenzidine (TMB). Density of wells was evaluated by spectrophotometry.

\section{Statistical Analysis}

Date were analysed using Statistical Package for the Social Sciences (SPSS) version 22 (Turkey). The normal distribution of parameters were evaluated by Kolmogorov-Smirnov and Shapiro Wilks tests and the parameters were found to be distrubuted normally. Student t-test was used to compare quantitative data between two groups. Paired sample t-test was used in the first and final weight comparisons of the parameters in the group, and Pearson correlation analysis was used when the relations between the parameters were examined. Means $(\overline{\mathrm{x}})$ and standard deviations (SD) were calculated where applicable. Significant difference was assessed at $\mathrm{p}<0.05$ level.

\section{RESULTS}

\section{Weight Change of Groups}

The mean weight of the study and control group at the first day was $26.63 \pm 3.02 \mathrm{~g}$ and $27.06 \pm 2.27 \mathrm{~g}$, respectively. There was no statistically significant difference between the groups in terms of initial weight averages ( $p>0.05)$. When the groups are compared in 
terms of weight average on the seventh day; the study group had significantly lower mean weight on the day $7(22.11 \pm 3.22 \mathrm{~g})$ than the control group $(28.63 \pm 3.80 \mathrm{~g})$ $(p<0.05)$. The decrease in the weight averages of 1 st and 7 th days was also statistically significant $(\mathrm{p}<0.05)$ in the study group. In the control group, the weight averages of 1 st and 7th days were increased, but the differences were not significant ( $p>0.05$ ) (Table 1).

\section{Right Gastrocnemius Muscle Weights}

The mean right gastrocnemius muscle weights of the study and control groups after sacrification were $0.09 \pm 0.03 \mathrm{~g}$ and $0.12 \pm 0.02 \mathrm{~g}$, respectively. The mean right gastrocnemius muscle weight of the study group was found to be significantly lower than the control group $(\mathrm{p}<0.05)$.

\section{mTOR and Myogenin Levels}

There were no significant differences in the mean values of mTOR and myogenin levels between groups after the administration of resveratrol $(\mathrm{p}=0.227$ and $\mathrm{p}=0.548$, respectivelly) (Table 2).

There were no relationship between mTOR and myogenin levels and 7th day total body weight and muscle weight for both groups ( $p>0.05)$ (Table 3 ).

Table 1. Comparision of groups 1st and 7th day weights

\begin{tabular}{lccc}
\hline \multirow{2}{*}{ Weight (g) } & Study Group & Control Group & \\
\cline { 2 - 3 } & $\overline{\mathbf{X}} \pm \mathbf{S D}$ & $\mathbf{\mathbf { X }} \pm \mathbf{S D}$ & \\
\hline 1st day & $26.63 \pm 3.02$ & $27.06 \pm 2.27$ & 0.769 \\
7 th day & $22.11 \pm 3.22$ & $28.63 \pm 3.80$ & $0.005^{\ddagger}$ \\
Difference & $-4.51 \pm 2.89$ & $1.57 \pm 1.73$ & $0.001^{\ddagger}$ \\
$\dagger \mathbf{\dagger}$ & $\mathbf{0 . 0 0 6}+$ & $\mathbf{0 . 0 5 4}$ & \\
\hline${ }^{*}$ Student $t$ test ${ }^{\dagger}$ paired sample $t$ test ${ }^{*} p<0.05$ & &
\end{tabular}

\section{DISCUSSION}

Resveratrol can exert an interesting benefit in skeletal muscle (18) and it is proposed that; it can protect muscle mass in catabolic processes thought affecting mTOR and various signaling pathways $(15,19)$. Therefore RSV is suggested to be an important strategy for the development of muscle mass (15). In this study, we aimed to investigate RSV effect on muscle mass and myogenesis (myoglobin), and anabolic (mTOR) markers.

In a study, treatment with RSV caused an increase in myotubul size, elongation in heights and it highlighted that RSV can control myogenesis and hypertrophy (16). It has also been reported in several studies that resveratrol reduces protein degradation $(17,20)$. In another study RSV treatment not only attenuated TNF-a induced atrophic response but also promoted hypertrophic processes in myotubules by regulating the activity of Akt/mTOR pathway (15). In contrast to literature; in the present study, muscle weights of the study group were significantly lower than control groups' (respectively, $0.09 \pm 0.03 \mathrm{~g}$ and $0.12 \pm 0.02 \mathrm{~g}$, $\mathrm{p}<0.05$ ) (Table 1).

mTOR participates in many biological functions such as gene transcription, protein translation, and ribosome

Table 2. Evaluation of groups according to mTOR and myogenin levels

\begin{tabular}{lccc}
\hline & Study Group & Control Group & \multirow{2}{*}{$* \mathbf{p}$} \\
\cline { 2 - 3 } & $\overline{\mathbf{X}} \pm \mathbf{S D}$ & $\overline{\mathbf{X}} \pm$ SD & \\
\hline mTOR (ng/g) & $4.40 \pm 0.35$ & $4.63 \pm 0.32$ & 0.227 \\
Myogenin $(\mathrm{ng} / \mathrm{g})$ & $6.17 \pm 0.23$ & $6.12 \pm 0.04$ & 0.548 \\
\hline Student $t$ test $p<0.05$ & & &
\end{tabular}

Table 3. Relationship of mTOR, myogenin levels and 7th day body weight and muscle weight for study and control groups

\begin{tabular}{lccccccccc}
\hline & \multicolumn{4}{c}{ Study Group } & \multicolumn{3}{c}{ Control Group } \\
\cline { 2 - 8 } & \multicolumn{2}{c}{ mTOR (ng/g) } & \multicolumn{2}{c}{ Myogenin (ng/g) } & \multicolumn{2}{c}{ mTOR (ng/g) } & Myogenin (ng/g) \\
\hline 7th Day & $\mathrm{r}$ & $\mathrm{p}$ & $\mathrm{r}$ & $\mathrm{p}$ & $\mathrm{r}$ & $\mathrm{p}$ & $\mathrm{r}$ & $\mathrm{p}$ \\
\hline Body weight (g) & -0.075 & 0.873 & -0.038 & 0.935 & 0.074 & 0.875 & -0.123 & 0.793 \\
Muscle weight (g) & -0.364 & 0.422 & -0.107 & 0.819 & 0.123 & 0.794 & -0.183 & 0.694
\end{tabular}


synthesis by integrating extracellular signals such as nutrients, growth factors, and energy substances in the physiological and pathophysiological processes of cells (21). One of the most widely recognized major players in controlling muscle mass. A decreased activation of the Akt-mTOR pathway contributes to protein synthesis reduction, which can occur under disuse conditions or after a low protein diet (18). In a study RSV and exercise combination effects on muscle mass, mTOR and myogenin levels were studied. It was found that at the 7th day, mTOR levels of resveratrol and resveratrol+exercise groups were increased compared to other groups and the authors concluded that on the behalf of mTOR expression, RSV may have stimulated anabolic pathway (22). Although there are lots of studies indicating that RSV can regulate Akt/ mTor process, so give a contribution to muscle gain $(15,16)$. In our study RSV didn't make any difference on the mTOR and myogenin levels. And despite mTOR level was not statistically different from the control group and we randomly found muscle mass decrease in the study group $(\mathrm{p}=0.227)$ (Table 2). However according to the literature if there is a muscle loss it is often related with Akt/mTOR pathway downregulation (23), in contrary with that we didn't find any relation between mucle mass and mTOR- myogenin levels (respectively, $\mathrm{p}=0.422, \mathrm{p}=0.819$ ) (Table 3 ).

Resveratrol has been reported to have active role in muscle cell differentiation (16) and upregulates muscle pre-differentiation markers and transcriptional factors (myogenin, Scrp3), and strongly enhances myosin heavy chain content (24). Accorging to a study RSV stimulates early expression of MRFs (such as Myf-5, MyoD, and myogenin) and promotes muscle indicator proteins (myosin heavy chain) and skeletal structural protein processes and exerts positive effect on hypertrophy through stimulating IGF-1 pathway. As a result, RSV can control myogenesis and hypertrophy (16). In a study investigating RSV and RSV+exercise combination effect on muscle mass, mTOR and myogenin levels; it was found that at the 7th day, RSV group myogenin expression increased compared to control group. With that results authors concluded that, RSV is likely to favor differentiation by increasing myogenin, possibly contributing to enhanced myogenesis in addition to increased protein synthesis and muscle anabolism (22). Conflicting with literature, in our study RSV did not cause any difference in myogenin levels compared with control group ( $\mathrm{p}=0.548$ ) (Table 2). It was unexpected results that we found weight and muscle loss, while we were trying to examine myogenic factors but not examining the pellet consumption or other conditions which could give such a reason. There is also data about RSV and weight loss effect (25-27) but it wasn't the main purpose of this study so we don't have any date to argue it.

\section{CONCLUSION}

Resveratrol is a frequently studied compound in the literature, but its effects on skeletal muscle are relatively less studied. Myogenin and mTOR are stated to be key molecules for prevention of muscle atrophies and are very important kinase and trancriptional factors for muscle hypertrophy. In our study unexpectedly we experience weight loss and gastrocnemius muscle mass decrease in resveratrol group. Despite the muscle mass decrease in the study group, there was no difference in mTOR and myogenin levels among the groups. The effects of resveratrol on muscle tissue is a relatively less studied issue. However, the authors are suggesting more studies about the resveratrol usage or administration for the effective dose and time interval investigation.

Conflict of interest: The authors declare that they have no conflict of interest.

Funding source: This study was supported by Başkent University Medical and Health Sciences Research Board.

\section{REFERENCES}

1. Repossi G, Das UN, Eynard AR. Molecular basis of the beneficial actions of resveratrol. Arch Med Res. 2020;51:105-14.

2. Saldanha FJ, Leal OV, Stenvinkel P, Carraro-Eduardo CJ, Mafra D. Resveratrol: Why is it a promising therapy for 
chronic kidney disease patients?. Oxid Med Cell Longev. 2013;963217-6.

3. Zeng Z, Chen X, Huang Z, Chen D, He J, Chen H, et al. Effects of dietary resveratrol supplementation on growth performance and muscle fiber type transformation in weaned piglets. Anim Feed Sci Technol. 2020;265:114499.

4. Wu ER, Huang CW, Liao CC, Chang YK, Kan NW, Huang CC. Resveratrol protects against physical fatique and improves exercise performance in mice. Molecules. 2013;18:4689-702.

5. Gomez-Cabrera MC, Arc-Chagnaud C, Salvador-Pascual A, Brioche T, Chopard A, Olaso-Gonzalez G, et al. Redox modulation of muscle mass and function. Redox Biol. 2020;35(101531):1-11.

6. Hao D, Wang X, Wang X, Thomsen B, Kadarmideen HN, Lan X, et al. Transcriptomic changes in bovine skeletal muscle cells after resveratrol treatment. Gene. 2020;754:144849.

7. Widlund AL, Baur JA, Vang O. mTOR: More targets of resveratrol? Expert Rev Mol Med. 2013;15:10-25.

8. Lai KM, Gonzalez M, Poueymirou WT, Kline WO, Na E, Zlotchenko E, et al. Conditional activation of Akt in adult skeletal muscle induces rapid hypertrophy. Mol Cell Biol. 2004;24(21):9295-304.

9. Bentzinger FC, Wang XY, Rudnicki AM. Building muscle: Molecular regulation of myogenesis. Cold Spring Harb Perspect Biol. 2012;4(2):a008342.

10. Knight DR-J, Kothary R. The myogenic kinome: Protein kinase critical to mammalian skeletal myogenesis. Skelet Muscle. 2011;1(29):1-18.

11. Park CE, Kim MJ, Lee JH, Min BI, Bae H, Choe W, et al. Resveratrol stimulates glucose transport in C2C12 myotubes by activating AMP-activated protein kinase. Exp Mol Med. 2007;39(2):222-9.

12. Shen H, Lv Y, Shen XQ, Xu JH, Lu H, Fu LC, et al. Implantation of muscle satellite cells overexpressing myogenin denervated muscle atrophy in rats. Braz J Med Biol Res. 2016;46(2):5124-30.

13. Fu X, Zhao JX, Liang J, Zhu MJ, Foretz M, Viollet B, et al. AMP-activated protein kinase mediates myogenin expression and myogenesis via histone deacetylase 5 . Am J Physiol Cell Physiol. 2013;305:887-95.

14. Wen W, Chen X, Huang Z, Chen D, Chen H, Luo Y, et al. Resveratrol regulates muscle fiber type conversion via miR-22-3p and AMPK/SIRT1/PGC-1a pathway. J Nutr Biochem. 2020;77:108297.

15. Wang DT, Ying Y, Yang YJ, Lv PJ, Shi Y, Lu L, et al.
Resveratrol prevents TNF- $a$ - induced muscle atrophy via regulation of Akt/mTOR/Fox01 signaling in C2C12 myotubes. Int Immunopharmacol. 2014;19(2):206.

16. Montesano A, Luzi L, Senesi P, Mazzocchi N, Terruzzi I. Resveratrol promotes myogenesis and hypertrophy in murine myoblasts. J Transl Med. 2013;11:310.

17. Russell ST, Wyke SM, Tisdale MJ. Mechanism of induction of muscle protein degradation by angiotensin II. Cell Signal. 2006;18:1087-96.

18. Salucci S, Falcieri E. Polyphenols and their potential role in preventing skeletal muscle atrophy. Nutr Res. 2020;74:10-22.

19. Alamdari N, Aversa Z, Castillero E, Gurav A, Petkova V, Tizio S, et al. Resveratrol prevents dexamethasoneinduced expression of the muscle atrophy-related ubiquitin ligases atrogin-1 and MuRF1 in cultured myotubes through a SIRT1-dependent mechanism. Biochem Biophys Res Commun. 2012;417(1):528-33.

20. Wyke SM, Tisdale MJ. Induction of protein degradation in skeletal muscle by a phorbol ester involves upregulation of the ubiquitin-proteasome proteolytic pathway. Life Sci. 2016;78:2898-910.

21. Xu T, Sun D, Chen Y, Ouyang L. Targeting mTOR for fighting diseases: A revisited review of mTOR inhibitors. Eur. J. Med. Chem. 2020;199:112391.

22. Salomão RAS, De Paula TG, Zanella BTT, Carvalho PLPF, Da Silva Duran BO, Valente JS, et al. The combination of resveratrol and exercise enhances muscle growth characteristics in pacu (Piaractus mesopotamicus). Comp Biochem Physiol A Mol Integr Physiol. 2019;235:46-55.

23. Bodine SC, Stitt TN, Gonzalez M, Kline WO, Stover GL, Bauerlein R, et al. Akt/mTOR pathway is a crucial regulator of skeletal muscle hypertrophy and can prevent muscle atrophy in vivo. Nat Cell Biol. 2001;3(11):1014-9.

24. Kaminski J, Lançon A, Aires V, Limagne E, Tili E, Michaille JJ, et al. Resveratrol initiates differentiation of mouse skeletal muscle-derived C2C12 myoblasts. Biochem Pharmacol. 2012;84(10):1251.

25. Chachay VS, Macdonald GA, Martin JH, Whitehead JP, O'Moore-Sullivan TM, Lee P, et al. Resveratrol does not benefit patients with nonalcoholic fatty liver disease. Clin Gastroenterol Hepatol. 2014;12(12):1-6.

26. Hosseini A, Ghorbani A. Cancer therapy with phytochemicals: Evidence from clinical studies. AJP. 2015;5(2):84-97.

27. Sales MF, Resurreccion AVA. Resveratrol in peanuts. Crit Rev Food Sci Nutr. 2014;54:732-70. 